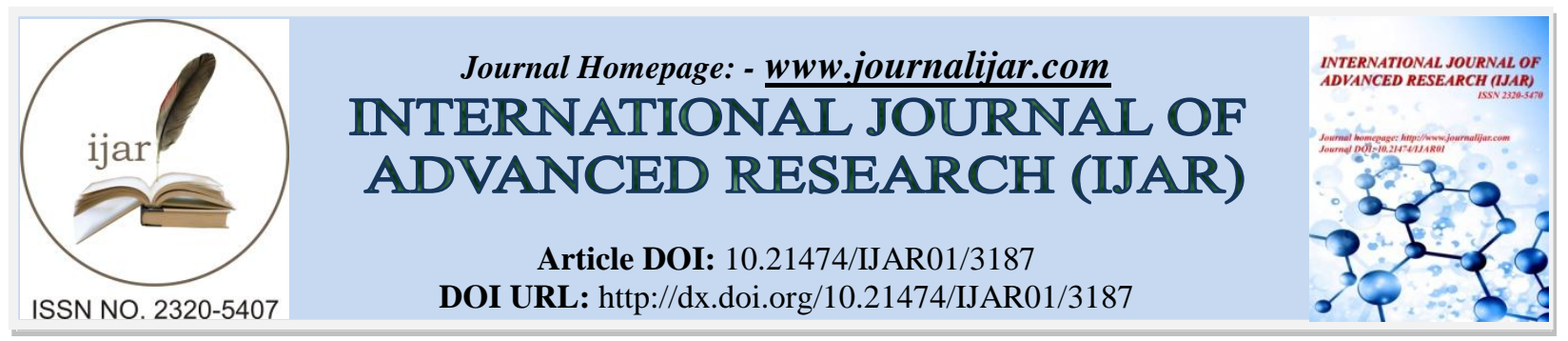

RESEARCH ARTICLE

\title{
THE ROLE OF BANKING SUPERVISION IN ACHIEVING THE OBJECTIVES OF MONETARY POLICY
}

\section{Dr. Ghassan Farouk Ghandour.}

College of Financial \& Administration-Department of Accounting \& IT, Cihan University/ Sulaiymani, Kurdistan Region Government/Iraq.

\section{Manuscript Info}

\section{Manuscript History}

Received: 08 December 2016

Final Accepted: 115 January 2017

Published: February 2017

\section{Key words:-}

monetary policy, banking supervision, the exchange rate, the interest rate, the reserve requirement

\begin{abstract}
The safety of the national economy and the effectiveness of monetary policy of any country depend on the safety of the financial system and in particular the safety of banks as, it is one of the main pillars in the financial system for its compilation of national saving and its re-employment in the service of all the economic activities.

Hence this study comes to identify the importance of the supervision of the banking sector in order to keep the stability and efficiency of the banking system. This is to reach to safe and stable banking sector that keeps the rights of depositors and investors and ensures the safety of executing the monetary policy for the country and achieving its objectives
\end{abstract}

Copy Right, IJAR, 2017,. All rights reserved.

\section{Introduction:-}

Macroeconomic variables constitute the general framework of economic policies that achieve their goals through harmonious and consistent monetary and financial policies package. The transfer channels of the impact of monetary policy activation requires the completion of effective supervision of the banking sector respond to the latest international standards in the field of banking supervision, so as to ensure the central bank to exercise its role effectively in controlling the banking system and activating its role so as to ensure readiness to play its role in the transfer of the impact of monetary policy to the real economy sector, the banking sector in response to lower interest rates to expand their lending to secure the necessary funding for the investment sector is the basic and necessary and sufficient condition to achieve monetary policy to activate investment and increase employment and achieve economic growth and development.

\section{Research problem:-}

The banking system in Syria suffer of weakness supervision of the Central Bank on public and private banks due to the absence of a flexible legislative framework is able to intervene and compel the banks to oblige with the procedures intended to do, from this point should stand on concrete facts showing that the impact of supervision of the banks in achieving the objectives of monetary policy In Syria.

\section{Research importance:-}

The transfer channels of the impact of monetary policy in Syria activation requires the completion of effective supervision of the banks respond to the latest international standards in the field of banking supervision, so as to ensure the central bank to exercise its role effectively in the banking system, and activating its role so as to ensure it is ready to play its role in the transfer of the impact of monetary policy to the real economy sector. 


\section{Research objectives:-}

This research aims to know the reality of banking supervision in Syria, and the supervision of the Central Bank of Syria, to determine the requirements that must be met to achieve the objectives of monetary policy and the transfer of its impact to the real economy sector. Moreover, this research aims to build financial and statistical models that help in measuring the impact of banking supervision in the economic variables.

\section{Research hypotheses:-}

The study deals in the period (2001 - 2010) is the stage of the Central Bank of Syria of adopting a policy of banking supervision, according to the latest international banking standards (the application of Basel), and thus will be testing a number of hypotheses which is:

1. There is no impact on Banking Supervision in Syria in the exchange rate.

2. There is no impact on Banking Supervision in Syria in the interest rate.

3. There is no impact on Banking Supervision in Syria in the development of reserve requirement.

\section{Research Methodology:-}

We will be relying of this research on the descriptive and analytical approach, as will study the relationship between banking supervision vocabulary and variables of monetary policy through the use of the software package statistical (SPSS) to analyze the results, depending on the method of least squares (OLS) in estimates different models.

First: The role of the monetary authority in the banking regulation and supervision on him:-

Most historical studies refer to the evolution of the monetary and banking systems, there are two main reasons for the establishment of central banks, the first regulate of monetary issuance process and control of money supply, and the second banking regulation and supervision, and contributes both to provide for the banking sector with stable environment, which ensures the safety of its operations.

And therefore can determine the role of the monetary authority in the banking regulation and ensure the safety and stability of the banking sector through two perspectives are perspective drawing of monetary policy and banking supervision perspective.

\section{The monetary function of monetary authority:-}

The central bank seeks to draw a clear-cut monetary policy contributes to increased GDP, and then raise the economic growth rate in coordination and cooperation with the government in order to maintain macroeconomic stability (Hankel, Holtkemper, 2008: p15), where it is considered an effective monetary policy regarding for adjust the changes in rates of economic growth (Bernank, Mishkin, 2001: p2), with the aim of influencing in the macroeconomic variables and achieve monetary and banking stability, which contributes to the achievement of the following general economic objectives (John B, 2000: p45):

* High growth rates.

* Complete use of resources.

* Stability of exchange rate.

* Equiponderate of payment balance.

As well as these goals are targets final have the intermediate objectives of three is the money supply, the interest rate, and the exchange rate, and through these intermediate objectives that, if it was used of monetary policy instruments, consistent with the requirements of the national economy can contribute to achieving the target goals of monetary policy (Bank of Japan, 1995: June)

In practice, it has become the responsibility of monetary policy primarily focused on achieving monetary stability, which contributes to the achievement of other objectives (Burdekin, Lorey, 1988: p41).

In this day's most of the economic trends focused on that price stability is the most important targets objectives of monetary policy (La monnaie, 1992: p21), so the trend today revolves around the concentration of the objectives of monetary policy on the prime objective is achieving price stability, particularly in the event of a conflict in the short term among other goals of monetary policy which confuses the monetary authorities (Fredric, 2004: P 414), It can be classified the instruments of monetary policy as follows: 


\section{Direct instruments:-}

A direct instruments of monetary policy include decisions issued by the monetary authorities in the context of managing monetary policy and supervision of banks.

\section{Indirect instruments:-}

The indirect instruments of monetary policy in three main instruments are:

\section{The development of the reserve requirements:-}

Reserve requirements are one of the instruments used by the central bank to protect depositors' accounts in the event that the bank's risk on the one hand, as well as its importance to control the liquidity of the banks on the other.

\section{The discount rate:-}

The discount rate as the rate of interest charged by the central bank to meet the re-discount at commercial banks from securities and treasury bills or meet it by the loans (Weaver, 2009: 158). And the consequent change the discount rate change in market interest rates, which affect on the credit and thus on the money supply.

\section{Open market operations:-}

the open market operations have a significant impact on the players behavior within the financial market through the channel of expectations, where they are used as an indicator to predict the movements of interest rates in the short and medium term and predict of the changes of government bond prices and their impact on other securities prices, also plays a role predicting the direction of monetary policy and forecasting inflation or recession (Stanley, McConell, 2008: p261) and therefore can be said that open-market operations generate three types of effects in the money markets and capital, the first is the effect of bank reserves and the growth of the monetary base and money supply, and the second issue is to influence the security prices and interest rates the short-term at least, and the third is represented the impact of the economic expectations (Thomas, 1997, P.400).

\section{The supervisory function of monetary authority:-}

The goal of the banking stability is as important as monetary stability as monetary and banking stability are two sides of the same coin, central bank will not be able to achieve monetary stability if the banking sector is not stable. Often the central bank as a empowered with the function of supervision of the banking sector, where the competent authority at the central bank (Crocket, 2005, P2) to follow up the functions of banks and lay the standards that regulate banking operations and ensure the safety and efficiency of its work and maintain depositors' account and protect the banking system from falling into a crisis.

The monetary authority between the monetary and supervisory functions:-

There are many views about determine of the head of banking supervision authority, In this framework, the countries were divided into three main groups (Daniel, William, 1993, 1997):

\section{The first group:-}

The group of countries for which the central bank's on banking supervision, which is called the model of the Central Bank

\section{The second group:-}

The group of countries that are the supervisory bodies and specialized on Banking Supervision in cooperation with the Central Bank and Ministry of Finance.

The third group: the Group of countries that the Ministry of Finance or bodies and specialized only on Banking Supervision, and called on the second and third groups are the alternative model of Banking Supervision.

Second:- The descriptive analysis of the impact of banking supervision in achieving the objectives of monetary policy in Syria:-

The monetary policy in Syria has seen a remarkable development after decades of stagnation through their quest to move from the neutral point, to lay the foundations of an effective monetary policy stage meets the needs of a market economy, through the activation of supply and demand forces in the pricing process, and the pursuit of full competition as a necessary condition to achieve of a market economy system. Hence monetary authorities sought with the beginning of 2005 to establish a strong foundation for monetary policy to take an active role in 
macroeconomic policies. Thus, in front of these arrangements and the foundations laid by the monetary authorities in Syria, we have to ask the following question:

\section{Is achieved monetary policy in Syria objectives aimed to?}

We will depend on the answer to this question on the review of the key elements of business strategy of the monetary policy adopted by the Central Bank of Syria after the issuance of the Basic monetary Law, and through the study of intermediate objectives for monetary policy / exchange rate /, the study of monetary policy instruments used on a practical level / interest rate and reserve requirements /, and the effectiveness of each of them in achieving the target goal of monetary policy / inflation control and the stability of the general level of prices /.

Table :- The evolution of the elements of monetary policy in Syria during the period (2001-2010)\%

\begin{tabular}{|l|l|l|l|l|l|l|l|l|l|l|}
\hline & 2001 & 2002 & 2003 & 2004 & 2005 & 2006 & 2007 & 2008 & 2009 & 2010 \\
\hline inflation rates & 0.81 & 0.6 & 7.45 & 4.17 & 7.41 & 10 & 4.5 & 15.15 & 2.8 & 4.4 \\
\hline $\begin{array}{l}\text { nominal } \\
\text { exchange rate }\end{array}$ & 3.1 & 1.38 & 0 & 1.16 & 5.08 & -6.84 & -5.87 & -3.62 & -1.4 & 2.63 \\
\hline $\begin{array}{l}\text { money supply } \\
\text { M2 rates }\end{array}$ & 1.35 & 19.9 & 8.15 & 13.4 & 11.8 & 9.16 & 12.4 & 12.46 & 9.2 & 12.4 \\
\hline $\begin{array}{l}\text { real interest rates } \\
\text { (time deposits) }\end{array}$ & 6.69 & 6.9 & -1 & 1.58 & 0.89 & -2.08 & 3.33 & -8.17 & 3.48 & 1.71 \\
\hline $\begin{array}{l}\text { real interest rates } \\
\text { (saving deposits) }\end{array}$ & 7.19 & 7.4 & -0.5 & 0.83 & -3.41 & -5.03 & 0.31 & -10.4 & 1.87 & -0.1 \\
\hline $\begin{array}{l}\text { reserve } \\
\text { requirements } \\
\text { rates }\end{array}$ & 61 & 33 & 14 & 51 & -21 & 173 & 51 & 116 & 9 & 16 \\
\hline Reference: Quarterly statistics, central bank of Syria (2001-2010) & & & & & \\
\hline
\end{tabular}

The impact of banking supervision in the exchange rate:-

The Figure (1) shows the evolution of each of the nominal exchange rate (Syrian pounds to the US dollar) and the inflation rates in the Syrian economy during the period (2001-2010).The figure (1) shows as follows:

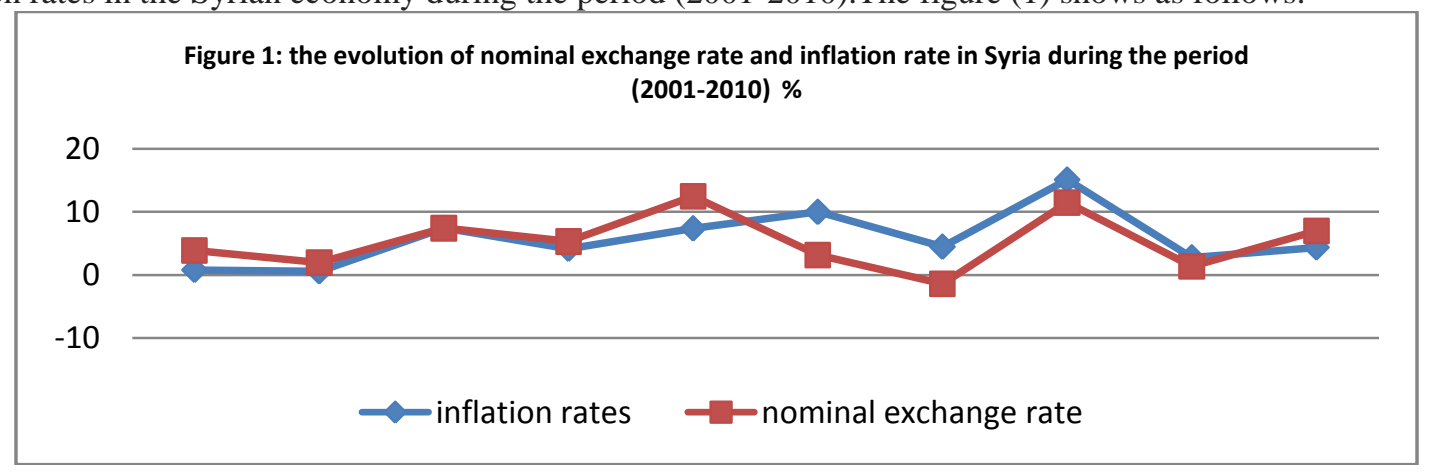

This period knew relatively stable in the Syrian pound exchange rate against the US dollar, as the track the evolution of the exchange rate during this period refers to keep the exchange rate stable with a gradual rise in the value of the Syrian pound since the beginning of 2006 against the US dollar, we see from the figure Previous (1) a rise in the value of the Syrian pound against the US dollar (the exchange L / d of $50.90 \mathrm{~L} / \mathrm{d}$ in 2001, the price fell to $46.90 \mathrm{~L} /$ $\mathrm{d}$ in 2010, to reach an average of $49.9 \mathrm{~L} / \mathrm{d}$ ), with reference to the Syrian pound has seen in previous years for 2010 gradually successive rises in value against the US dollar at a rate of $(6.8 \%, 5.9 \%, 3.6 \%, 1.4 \%)$ during the years (2006.2007, 2008.2009), respectively, We explain the stability in the exchange rate during this period as a result of procedures taken by the Syrian government during this period, which was mutually made an emergency landing in response to emergency conditions, others were focus on the strategy of the monetary policy of the Central Bank of Syria of targeting the Syrian pound exchange rate in the medium term in order to achieve price the target goal of monetary policy adopted by Syria in the long-term work on price stability and control inflation.

In contrast, we see a down the rate of inflation in Syria from $10.03 \%$ in 2006 to reach $4.4 \%$ in 2010. 
As can be seen from the figure (1) that there are relatively very weak consensus in the general direction of both inflation and exchange rate growth during this period, reflecting weak relationship between them, which is not shows importance of the exchange rate to control inflation.

The Impact of banking supervision in the interest rate:-

The Figure (2) shows the develop of each of the real interest rates (time deposits, and savings deposits) and the inflation rates in the Syrian economy during the period(2001-2010). The figure (2) shows as follows:

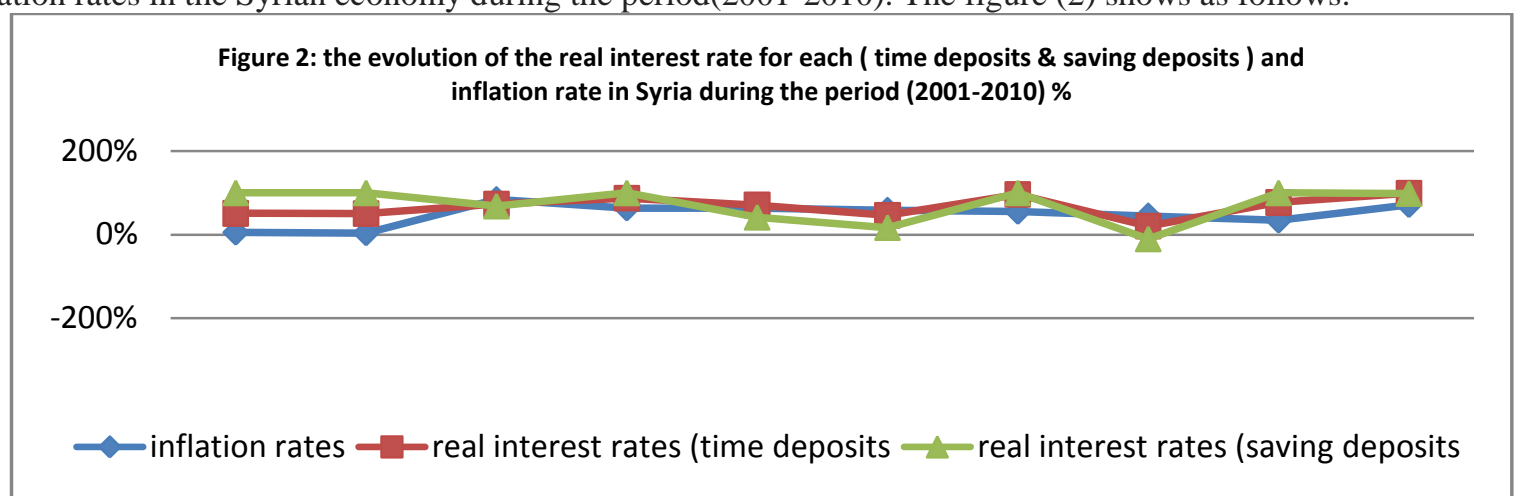

we observe the evolution of the real interest rate on time deposits it is clear that it was negative in the years (2003, $2006.2008)$ amounted respectively $(-0.95 \%,-2.08 \%,-8.17 \%)$, while the evolution of the real interest rate on savings deposits it is clear that it was negative during the years (2003, 2005.2006, 2008.2010) amounted respectively ($0.45 \%-3.41 \%-5.03 \%-10.36 \%-0.05 \%)$, we can explain that as a result of irregular rises in inflation during this period.

here is a defect in the performance of monetary policy in Syria, and the weakness in their ability to use interest rates as a monetary policy instruments in achieving the objectives of monetary policy, but it used the interest rates as a instrument to achieve a general economic policy objectives, from during their quest to restructure deposits in favor of long-term deposits in order to increase the financing capacity of the banking sector in Syria in the long term, but these deposits become piling up at banks without hiring a result of the weakness of investment channels necessary to employ this surplus liquidity in banks.

The Impact of banking supervision in the development of reserve requirements:-

The Figure (3) shows the evolution of both the reserve requirements rates of growth, and the evolution of the money supply M2 growth rates, and the evolution of inflation rates in the Syrian economy during the period (2001-2010).

The previous figure (3) shows as follows:-

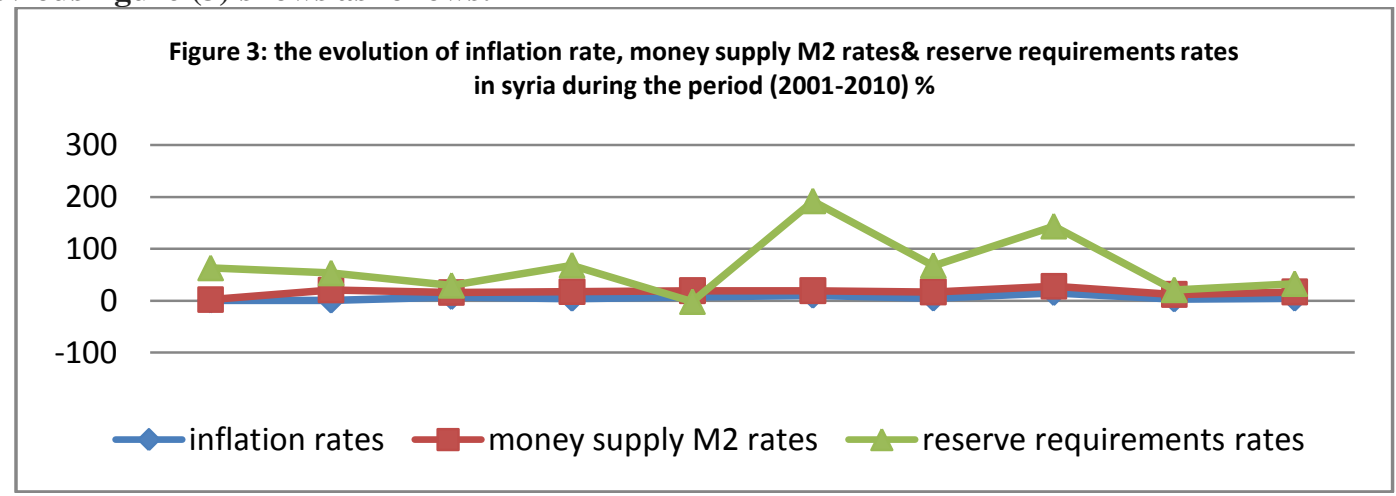

By tracking the evolution of the growth rates of the reserve requirement in Syrian pounds and foreign currency at the Central Bank of Syria, it is clear that it has seen a remarkable increase during the period studied were on average about $50 \%$, equivalent to five times the average growth of the reserve requirement rate, as the growth of reserve requirements rate rose from 51\% in 2004 to up to $173 \%-116 \%$ during the years 2006 to 2008 respectively, we can interpret that as a result of decisions taken by the monetary authorities in Syria during this stage that, Reflecting to a large extent the success of the decisions taken by the monetary authorities to raise the reserve requirement growth rates, but in return we observe the inability of monetary authorities in controlling the money supply growth rates 
through the use of the reserve requirement policy, where the relationship is completely separate from the reserve requirement growth rates and the growth of the money supply during the period (2004-2008)as shown by Figure(3) in despite of previous decisions taken by the monetary authorities, and therefore the reserve requirement policy has not affected during the period(2004-2008)in controlling the money supply growth rates, which confirms the ineffectiveness of using this tool in controlling the money supply growth rates during the period of study.

Then the reserve requirement rate of growth returned to decline very significantly reduced during the years 20092010 to reach $(9 \%, 16 \%)$, respectively, we can explain that as a result of decisions taken by the monetary authorities in Syria during these two years, which largely reflects the success of this decision to reduce the reserve requirement rates of growth, but in return we also observe that the monetary authorities were able to control rates money supply growth to some extent through the use of the policy of reserve requirement.

In contrast, inflation rates have witnessed a remarkable increase during this period to reach $10.3 \%$, $15.15 \%$ respectively 2006-2008, then returned to decrease again during 2009-2010 also to reach $2.8 \%$, 4.4\%, respectively. $\boldsymbol{\omega}$ As can be seen from Figure No. (3) earlier that there is a clear separate in the relationship between inflation and growth rates of reserve requirements in the period (2004-2008), having noted that with the rise in reserve requirements growth rates over the years 2006 to 2008 as mentioned previously, there was a contrast rise in inflation rates during the years 2006-2008, and then did not affect reserve requirements followed a policy at this stage in controlling high inflation.

As can be seen from Figure No. (3) that there is a clear break in the relationship between the inflation and the rates of the reserve requirements growth during 2009-2010, so that with low inflation rates in parallel with the decline in the growth of requirement reserve rates, however, this decline in inflation was caused by factors related to the economic policy of the government, it was not caused by monetary factors.

\section{Third: The Empirical Result and hypotheses testing:-}

After that study, the analytical side of the impact of banking supervision in achieving the objectives of monetary policy in Syria, which has shown that there is a weak effect of the impact of banking supervision policy in the various components of monetary policy that contributes to achieving the target goals of it, remain these effects known to use some standard methods, so through the use of statistical software package (SPSS) to analyze the results, depending on the method of ordinary least squares (OLS) to estimate the coefficients of various models.

\section{The first hypothesis: There is no impact on Banking Supervision in Syria in the exchange rate:-}

In order to measure the impact of banking supervision in Syria on the exchange rate will be depending on the model consists of the inflation rate as the dependent variable and the exchange rate growth as an independent variable in the period of study (2001-2010), and therefore the model is as follows: INF $=\alpha+\mathrm{a} \mathrm{EXCH}+£$

INF: inflation, EXCH: exchange rate growth rate, $\alpha$ : constant, $£$ : random error.

a: model coefficient represents the partial regression coefficient of the independent variable (the exchange rate growth rate).

When applying the model on the Syrian economy during the period of study (2001-2010) the results were as follows: INF $=5.514-0.507 \mathrm{EXCH}$

The model indicates that the value of coefficient of Pearson correlation between the inflation rate and exchange rate growth during the period of study (2001-2010) amounted to $\mathrm{R}=-0.450$, which is not significant and does not reflect statistical significance, because the $\mathrm{SIG}=\mathrm{P}-\mathrm{VALUE}=0.192$, which is greater than the level significance adopted in this study as $\infty=0.05$, though the value of the coefficient of determination $\mathrm{R}$ SQUARE $=0.203$, so if exchange rate growth rate explains only $20.3 \%$ of the variation or difference in the rate of inflation.

The P-VALUE corresponding statistical coefficient t to the constant and variable coefficients was respectively: $\mathrm{SIG}=\mathrm{P}-\mathrm{VALUE}=0.003$ for constant $\mathrm{SIG}=\mathrm{P}-\mathrm{VALUE}=0.192$ for the variable exchange rate growth rate

It is smaller than the significance level $\infty=0.05$ for constant coefficient, and for this we reject null hypothesis of this model since that at least one of regression coefficients /a/ and /b/ differ significantly from zero, indicating a moral calculated values and the quality of the estimated equation, shows importance of price growth rate exchange in effect at the rate of inflation. 
The test $\mathrm{F}$ amounted to 2.031 at the level of 0.05 when compared to the spreadsheet value, we find that the calculated value is greater than the spreadsheet value, which is show that the moral estimated whole model, and the significant coefficient of determination, and then we find that the independent variable had a significant impact on the regression.

The Regression coefficient shows that the exchange rate growth rate higher by one unit will lead to a decline in the inflation rate by 0.507 units, these contrasts with economic theory, where he was supposed to raise in the exchange rate leads to higher inflation, not falling.

The explanation of this is a result of emergency conditions and political pressures experienced by Syria during this stage, although enable the monetary authorities to secure the stability of the Syrian pound exchange rate against the US dollar through the intervention of the Central Bank of Syria buy and sell foreign exchange, which explains why the contradiction above between the exchange rate and inflation.

\section{The second hypothesis: There is no impact on Banking Supervision in Syria in the interest rate:-}

In order to measure the impact of banking supervision in Syria on the interest rate will be relying on the model consists of the inflation rate as the dependent variable, and the real interest rate on time deposits and the real interest rate on savings deposits as independent variables during the period of study (2001-2010), and therefore the model is as follows: INF $=\alpha+$ a INTERR-L + b INTERR-S $+£$

INF: inflation. INTERR-L: the real interest rates on time deposits. INTERR-S: the real interest rate on savings deposits.

A and b: model coefficients and represent a coefficient of partial regression for independent variables (the real interest rate on time deposits, the real interest rate on savings deposits). $\alpha$ : constant. $£$ : random error.

When applying the model on the Syrian economy during the period of study (2001-2010) the results were as follows: INF = 6.548 - 0.647 INTERR-L - 0.294 INTERR-S

The model indicates that the value of Pearson correlation coefficient between the rate of inflation and the real interest rate on time deposits, and savings deposits during the period of study (2001-2010) amounted to $\mathrm{R}=-0.981$, $\mathrm{R}=-0.968$, respectively, a moral and reflect statistically significant because the value of $\mathrm{SIG}=\mathrm{P}-\mathrm{value}=0.00$ for each, which is smaller than the significance level adopted in this study as $\infty=0.05$, though the value of the coefficient of determination of the model R SQUARE $=0.972$, so that the real rate of interest on both time deposits and savings deposits explains $97.2 \%$ of the variation or difference in the rate of inflation.

The P-VALUE corresponding statistical t to the constant and variable coefficients was respectively:

$\mathrm{SIG}=\mathrm{P}-\mathrm{VALUE}=0.000$ for constant $\mathrm{SIG}=\mathrm{P}-\mathrm{VALUE}=0.022$ to the variable of the real interest rate on time deposits for

It is less than the significance level $\infty=0.05$ for fixed coefficient, and the variable coefficient is real interest rate on time deposits, and for this we reject the null hypothesis for each of these coefficients, so they differ from zero, suggesting moral calculated values and the quality of the estimated equation, shows the importance of the real interest rate on time deposits in order to influence in the inflation rate.

While the P-VALUE corresponding statistical t to the variable coefficient is the real interest rate on savings deposits rate was $\mathrm{SIG}=\mathrm{P}-\mathrm{VALUE}=0.152$, which is greater than the significance level $\infty=0.05 \infty$ For that accept null hypothesis for this coefficient, that is equal zero, indicating not the moral values calculated and not the quality of the equation, which is not shows importance of the real interest rate on savings deposits for influencing in the inflation rate. The test $F$ value amounted to 121.471 at the level of 0.05 when compared to the spreadsheet value, we find that the calculated value is greater than the spreadsheet value, which is appropriate indicate that the regression is moral or that at least one of regression coefficients /a/ and /b/ differ significantly from zero.

The Partial regression coefficients show that the rise in real interest rates on time deposits increased by one unit price will lead to a decline in the inflation rate by 0.647 units, and the same applies if the real interest rate on savings deposits rose by one unit will lead to a decline less in the inflation rate by 0.294 units and this compatible with 
economic theory which is supposed to result in higher real interest leads to decrease inflation. It compatible perfectly with the economic reality in Syria during the period (2001-2010), which saw the monetary authorities in Syria by moving the interest rate after stability for about two decades, and track the evolution of each of the real interest rate on time deposits and savings deposits and the evolution of inflation in Syria It will be seen that during the years in which the inflation rate knew a high rise reflected the negative real interest rates on time deposits and savings deposits rates up to a maximum of 2008 to $\$(-8.17 \%,-10.36 \%)$, respectively.

The third hypothesis: There is no impact on Banking Supervision in Syria in the development of the reserve requirements:-

In order to measure the impact of banking supervision in Syria on the evolution of the reserve requirement will be depending on the model consists of the inflation rate as the dependent variable and the rate of reserve requirement growth as an independent variable in the period of study (2001-2010), and therefore the model is as follows: INF $=\alpha$ + a RESE $+£$

INF: inflation. RESE: the growth of reserve requirements in Syrian pound and foreign exchange growth. $\alpha$ : constant. $£$ : random error.

a: model coefficient represents the partial regression coefficient of the independent variable (the reserve requirement rate of growth).

When applying the model on the Syrian economy during the period of study (2001-2010) the results were as follows: $\mathrm{INF}=3.738+0.033$ FORASS

The model indicates that the value of Pearson correlation coefficient between the inflation rate and the rate of growth of reserve requirements during the period of study (2001-2010) amounted to $\mathrm{R}=0.438$, which is not significant and does not reflect statistically significant because the SIG $=$ P-VALUE $=0.205$, which is greater than the level of significance approved in this study, where $\infty=0.05$, though the value of the coefficient of determination R SQUARE $=0.192$, so the growth of reserve requirement rate explains $19.2 \%$ of the variation or difference in the rate of inflation.

The P-VALUE corresponding statistical t to the constant and variable coefficients was respectively:

$\mathrm{SIG}=\mathrm{P}-\mathrm{VALUE}=0.095$ for fixed $\mathrm{SIG}=\mathrm{P}-\mathrm{VALUE}=0.205$ for variable reserve requirement rate of growth

It is the largest of the significance level $\infty=0.05$ For that accept null hypothesis for this coefficient, that is equal to zero, which shows not of moral values calculated and not the quality of the estimated equation, shows not importance of the growth of reserve requirements in effect in the inflation rate.

The test F amounted to 1.899 at the significance level of 0.05 when compared to the value spreadsheet, we find that the calculated value is greater than the spreadsheet value, which is explain that the moral estimated whole model, and the significant coefficient of determination, and then we find that the independent variable had a significant impact on the regression.

The Regression coefficient shows that an increase in the reserve requirements growth rates by one unit will lead to an increase in the inflation rate by 0.033 units, and this above to not proceed with economic theory, where it was supposed to rise in reserve requirements leads to control the money supply growth rates, which helps in reducing the rate of inflation and not increase it. We can explain this contrasts as a result enable the monetary authorities in Syria to control the money supply growth rates in some years of this period and through the use of the reserve requirement policy, which has seen many decisions during this period contributed to achieve the objectives of monetary policy in Syria in the short term to control money supply growth rates, but they did not contribute to enable the monetary authorities to achieve the objectives of monetary policy in Syria in the long term by controlling the inflation rates during this period, and it is also mainly due to the causes of inflation during this period not related mainly to monetary reasons, but to other factors relating to the economic policy of the government in addition to general economic conditions experienced by Syria during this period. 


\section{Conclusions:-}

1. The creation of an efficient banking system, is capable of achieving the objectives of monetary policy and to ensure the stability of the banking, requires a regulatory system effective oversight and effective procedures on the banking sector, it aims to achieve the efficiency of the banking system.

2. There is no impact of Banking Supervision in Syria (the exchange rate, interest rate, and reserve requirements) during the period (2001-2010) according to:

The inability of monetary authorities during the period of study to control inflation and price stability as target goal in the long term, with the ability to achieve stability in the exchange rate as an intermediate objective of monetary policy as a result of central bank intervention to buy or sell, which contributes to control the rates of inflation in the Syrian economy, which has been unable to achieve the desired position because of the crises and emergency conditions experienced by Syria during this period, as well as government procedures aimed at liberalizing the exchange rate by shock and not gradually.

In despite of the policy of movement of interest rate by the monetary authorities during the period of study, but they were completely separate from changes in inflation rates during this period, which shows a deficit flaw in the performance of monetary policy in Syria during this period, and the inability to use the interest rate as a instrument to achieve objectives of monetary policy, but the use of interest rates to achieve a general economic policy of the government's objectives.

The inability of monetary authorities in Syria using the reserve requirement policy in controlling inflation during the period of study.

\section{Recommendations:-}

1. The supervisory authorities must carry out the review of decisions, and to ensure the continuing effectiveness of these decisions, and ensures application optimally, helping to strengthen the banking sector in Syria and increase its competitiveness.

2. the exchange rate unify policy requires the cancellation of controls on the exchange rate system gradually rather than liberation by shocked, and so by going to the flexibility in dealing in the foreign exchange market through the flotation system's reliance on a small scale in order to avoid the risks of sudden liberalization of the exchange market, this procedure corresponds to a thoughtful and conscious intervention of the Central Bank in the currency market to achieve the full liberalization of the exchange market, to meet the needs of the Syrian market of foreign exchange away from the intervention of the monetary authorities.

3. the policy of liberalization of interest rate must be gradually and consistent data Syrian economy, and in particular the structure of deposits and loans within the economy, especially that the liberalization of interest rates on loans along with the absence of open market operations will reflect negatively on the effectiveness of monetary market in Syria, as well as non-banking sector in Syria's ability to transfer the desirable impact of policy interest rate to influence the macro-economic variables because of the large value of the surplus liquidity has without financing.

4. We must follow up the development of the banking supervision process through the Central Bank of Syria's commitment to the principles of effective banking supervision, all the way to fully implement to ensure the preservation of a sound efficient system.

5. The strengthen of the independence of the Central Bank of Syria and resolve the entanglements between financial and monetary policies. 


\section{References:-}

1. Prof.Dr.wilhelm Hankel, Siegfried Holtkemper: the function of the central bank in a social market economy, technical cooperation between Germany and Syria, 2008.

2. Ben S. Bernank, Thomas Laubach, Fredric S. Mishkin, Adam S. Posen, and Inflation Targeting: Lessons from The International Experience, Princeton University Press, 2001.

3. Bank Of Japan, Inflation Targeting In Selected Countries, BIS Review, $9^{\text {th }}$. June 1995.

4. D. Brunell: La monnaie - Edition revue banque - Paris - 1992.

5. Mishken, Fredric, the Economics Of Money, Banking and Financial Markets $7^{\text {th }}$ Edition, 2004.

6. C.K.Burdekin, Richard and O .Laney, Lorey,"Fiscal Policymaking and Central Bank Institutional",Kikolo, vol .no.41,1988.

7. Taylor, JohnB: recent developments in the use of monetary policy rules, Stanford University, 2000.

8. FREDERICK S. WEAVER, Economic Literacy, Second Edition, British Library Cataloguing in Publication Information Available, 2009.

9. Brue Stanley \& Campbel McConell, Macroeconomics Principles, problems, and Policies, Seventeenth Edition, New Yorkk McGraw hill companies Inc., 2008.

10. Lioyd B. Thomas, Money Banking and Financial Markets, New York, Mc Graw, Hill companies Inc., 1997.

11. Andrew Crocket, Basle II: General Remarks, Beirut The $29^{\text {th }}$. Annual Meeting Of The Council Of The Governors Of Arab Central Banks \& Monetary Agencies, September, 2005.

12. Lundberg , Eduardo" Monetary Policy and Banking Supervision Function On Central Bank" Journal do Brazil, 05 ,July 2000.

13. Hardy,Daniel. C "Reserve Requirements and MonetaryManagement", IMF, working paper, Washington,1993.

14. Alexander, William E ,"Comment Banking Supervision Authority" ,In Current Legal Issues Affecting Central Banks, IMF, March1997.

15. WWW.Bank ofengland.co.uk/financialstability

16. Clement ,David "Conference Banks and Systemic Risk :Theory and Evidence ",England, 2001.

17. Andrew Crockett " Basel II: General Remarket " The Twenty Ninth Annual Meeting of the Council of the Governors of the Arab Central Banks \& Monetary Agencies, Beirut -Lebanon ,5 September 2005. 